\title{
Investigasi Air Tanah di Daerah Sea Kabupaten Minahasa Dengan Menggunakan Geolistrik Resistivitas Konfigurasi Dipol-Dipol
}

\author{
Adey Tanaumaa* ${ }^{a}$, Herling Daud Tangkuman ${ }^{b}$, Meiske Sangi ${ }^{b}$ \\ aJurusan Fisika, FMIPA, Unsrat, Manado \\ bJurusan Kimia, FMIPA, Unsrat, Manado
}

KATA K U N C I

Akuifer

Geolistrik

Resistivitas

\begin{abstract}
A B S T R A K
Penyebaran air tanah yang tidak merata dipengaruhi oleh faktor-faktor jenis batuan, bentuk topografi permukaan, jenis vegetasi dan jumlah curah hujan suatu tempat. Eksplorasi geofisika metode geolistrik tahanan jenis konfigurasi dipol-dipol digunakan untuk mengidentifikasi sebaran akuifer air tanah di desa Sea Kabupaten Minahasa. Data diolah menggunakan software Res2Dinv dan menghasilkan peta model resistivitas bawah permukaan 2 dimensi yang menggambarkan keadaan lapisan tanah. Teridentifikasi sebaran akuifer air tanah permukaan dengan kedalaman $\leq 20 \mathrm{~m}$ di sepanjang lintasan pengukuran. Akuifer air tanah dalam diidentifikasi pada lintasan 1 dengan kedalaman sampai $30 \mathrm{~m}$ dan $60 \mathrm{~m}$. Akuifer air tanah dengan kedalaman< 60 $\mathrm{m}$ mempunyai potensi dijadikan sebagai sumber air tanah
\end{abstract}

K E Y W O R D S

Aquifer

Geoelectric

Resistivity

\section{A B S T R A C T}

The uneven distribution of ground water is influenced by factors such as rock type, surface topography, vegetation type and the amount of rainfall in a place. Geophysical exploration of the dipole-dipole configuration type of geoelectric resistivity method is used to identify the distribution of groundwater aquifers in Sea village, Minahasa District. The data is processed using Res2Dinv software and produces a 2-dimensional subsurface resistivity model map that describes the state of the soil layer. Distribution of surface ground aquifer with a depth of $\leq 20 \mathrm{~m}$ along the measurement line was identified. Deepwater aquifers were identified in I1ne 1 with depths up to $30 \mathrm{~m}$ and $60 \mathrm{~m}$. Groundwater aquifers with a depth of $<60 \mathrm{~m}$ have the potential to be used as ground water sources

\begin{tabular}{l} 
TERSEDIA ONLINE \\
\hline 01 Februari 2020 \\
\hline
\end{tabular}

\section{Pendahuluan}

Air merupakan kebutuhan vital makhluk hidup. Manusia dalam memenuhi kebutuhannya akan air, memanfaatkan berbagai sumber seperti sungai, danau, dan air tanah. Air tanah terdapat didalam akuifer yaitu lapisan tanah yang mengandung air, ada yang bersifat akuifer permukaan dan ada yang bersifat akuifer air tanah dalam. Akuifer sendiri pada setiap daerah memiliki kedalaman yang berbeda-beda bergantung pada struktur tanahnya (Suryo dkk, 2016). Pada daerah dengan elevasi rendah biasa didominasi oleh keberadaan akuifer air tanah permukaan yang umumnya merupakan air resapan. Akuifer air tanah relatif mudah didapatkan pada daerah elevasi rendah hingga sedang, sementara hal sebaliknya terjadi pada daerah dengan elevasi tinggi.

Keberadaan akuifer air tanah dapat diketahui dengan mengidentifikasi formasi batuan dan struktur bawah permukaan berdasarkan nilai resistivitas dengan menggunakan geolistrik (Wijaya, 2015). Metode geolistrik yang sering digunakan salah satunya adalah geolistrik tahanan jenis. Metode ini dilakukan dengan menginjeksikan arus listrik ke dalam permukaan bumi melalui sepasang elektroda arus yang kemudian responsnya ditangkap oleh sepasang elektroda potensial. Beberapa kajian pemanfaatan metode geolistrik untuk mengidentifkasi akuifer air tanah telah 
dilakukan antara lain oleh Koyong dkk (2017), Wijaya (2015), Sulu dkk (2015), serta Sharifi et al (2014).

Resistivitas atau tahanan jenis suatu bahan adalah besaran atau parameter yang menunjukkan tingkat hambatan terhadap arus listrik. Bahan dengan resistivitas yang makin besar, berarti makin sulit untuk dilalui arus listik. Bahan dengan resistansi $(R)$ mempunyai resistivitas $(\rho)$ berbentuk silinder seperti pada Gambar 1 berikut (Waluyo, dkk. 2005).

Metode geolistrik adalah salah satu metode eksplorasi geofisika untuk menyelidiki keadaan bawah permukaan dengan menggunakan sifat-sifat kelistrikan batuan. Sifat-sifat kelistrikan tersebut adalah tahanan jenis (Telford, 1990). Metode geolistrik juga merupakan metode untuk mengetahui perubahan tahanan jenis lapisan batuan di bawah permukaan tanah dengan cara mengalirkan arus listrik DC (Direct Current) yang mempunyai tegangan tinggi ke dalam tanah.

Injeksi arus listrik ini menggunakan 2 elektroda arus A dan B yang ditancapkan ke dalam tanah dengan jarak tertentu. Semakin panjang jarak elektroda $\mathrm{AB}$ akan menyebabkan aliran arus listrik bisa menembus lapisan batuan lebih dalam. Aliran arus listrik akan menimbulkan tegangan listrik di dalam tanah. Tegangan listrik yang terdapat di permukaan tanah menggunakan 2 elektroda tegangan $\mathrm{M}$ dan $\mathrm{N}$ yang jaraknya lebih pendek dari pada jarak elektroda AB. Bila posisi jarak elektroda $A B$ diubah menjadi lebih besar maka tegangan listrik yang terjadi pada elektroda MN ikut berubah sesuai dengan informasi jenis batuan yang teraliri arus listrik pada kedalaman yang lebih besar (Hewaidy dkk, 2015).

As'ari dan Tongkukut, 2017 telah memetakan keberadaan akuifer air tanah di Universitas Sam Ratulangi, bahwa akuifer air tanah dengan resistivitas $\leq 10 \Omega \mathrm{m}$, potensi akumulasi akuifer air tanah besar ditemukan di : lintasan 1 pada elektroda ke 24 - 35 (meter ke 240 - 350)dengan kedalaman $\geq 20 \mathrm{~m}$, lintasan 2 pada elektroda 23 30 (meter ke 230 - 300) dengan kedalaman 5 - 25 $\mathrm{m}$

\footnotetext{
Material dan Metode

Kegiatan penelitian dilaksanakan dengan tahapan: survey pendahuluan, pengambilan data dilapangan, pengolahan data di Laboratorium Geofisika FMIPA Unsrat. Lokasi penelitian adalah di daerah Sea Kabupaten Minahasa (Gambar 1).

Pengambilan data geolistrik akan dilakukan dengan menggunakan gabungan teknik resistivity sounding dan resistivity mapping untuk mendapatkan profil 2D. Teknik sounding bertujuan memperkirakan distribusi harga resistivitas sebagai fungsi dari kedalaman pada suatu titik pengukuran, teknik mapping bertujuan untuk mengetahui variasi resistivitas secara lateral pada suatu daerah tertentu. Konfigurasi elektroda yang digunakan adalah konfigurasi dipol-dipol. Alat-alat yang
}

digunakan dalam pengukuran adalah satu set alat geolistrik resistivitymeter: Multi-Channel and MultiElectrode Resistivity and IP Meter MAE X612-EM , GPS (Global Postioning System), dan laptop.

Data pengukuran diolah menggunakan perangkat lunak notepad dan Res2Dinv, menghasilkan model tampang lintang resistivitas 2 dimensi. Peta model tampang lintang resistivitas menggambarkan kondisi lapisan tanah di bawah permukaan. Berdasarkan peta model ini diinterpretasi dan ditafsirkan keberadaan akuifer dan hidrologi bawah permukaan daerah penelitian.

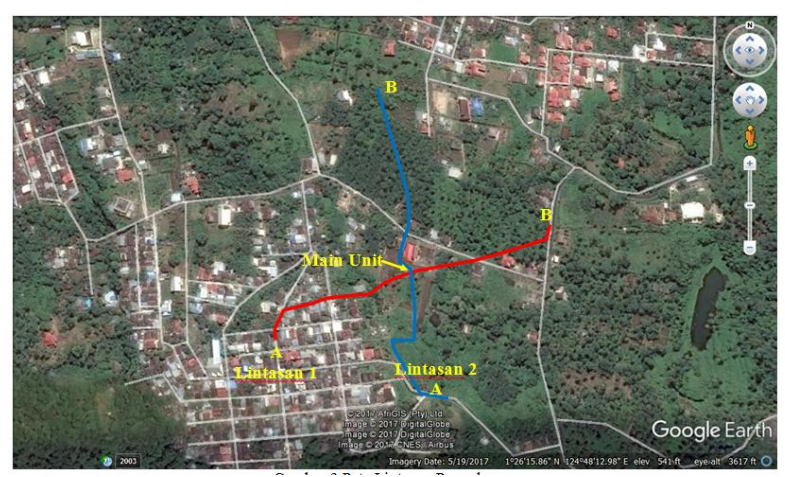

Gambar 1. Peta lintasan pengukuran

\begin{abstract}
Hasil dan Pembahasan
Pengambilan data dilakukan pada 2 lintasan, panjang lintasan 480 m, 48 buah elektroda, spasi antar elektroda $10 \mathrm{~m}$. Keadaan lapisan tanah di bawah permukaan diwakili oleh variasi resistivitas. Gambar 2 menunjukkan tampang lintang resistivitas lintasan 1. Lapisan tanah yang mengandung air (akuifer) mempunyai resistivitas $\leq 57,5 \Omega \mathrm{m}$, tersebar di sepanjang lintasan.
\end{abstract}

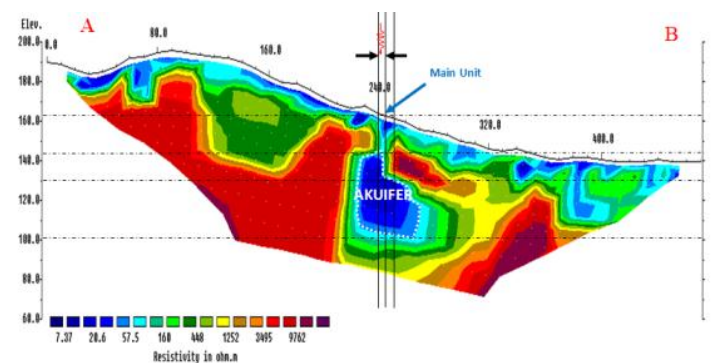

Gambar 2. Tampang lintang bawah permukaan lintasan 1

Akuifer air tanah permukaan mempunyai kedalaman $\leq 20 \mathrm{~m}$. akuifer terhubungkan satu dengan yang lain melalui area resapan (57,5 $\Omega \mathrm{m}<$ $\rho<108 \Omega m)$. Akuifer air tanah dalam terletak pada kedalaman $>20 \mathrm{~m}$. diidentifikasi dua lokasi akuifer air tanah dalam, yaitu 1) pada meter ke 225 - 270 dengan kedalaman mencapai $60 \mathrm{~m}$ dan 2) pada meter ke 380 - 400 dengan kedalaman < 30 m. akuifer pertama mempunyai potensi untuk dijadikan sebagai sumber air, diduga mempunyai cadangan jumlah air yang cukup besar.

Gambar 3 memperlihatkan tampang lintang resistivitas 2 dimensi lintasan 2 . Teridentifikasi akuifer air tanah permukaan dengan kedalaman $\leq$ 
$20 \mathrm{~m}$, terletak pada meter ke 160 - 455. Pada meter ke 80 - 140 terdapat lapisan menyeruapi akuifer tetapi dengan nilai kandungan air rendah ( $80 \Omega \mathrm{m}<\rho<149 \Omega \mathrm{m}$ ), kedalaman mencapai $35 \mathrm{~m}$. Kondisi ini diperkirakan karena bentuk topografi permukaan yang sangat miring sehingga kurang memberikan waktu bagi air hujan untuk meresap ke bawah permukaan, juga dipengaruhi faktor vegetasi yang hanya berupa rumput ilalang. Berdasarkan kondisi ini air hujan hanya runoff saja di permukaan.

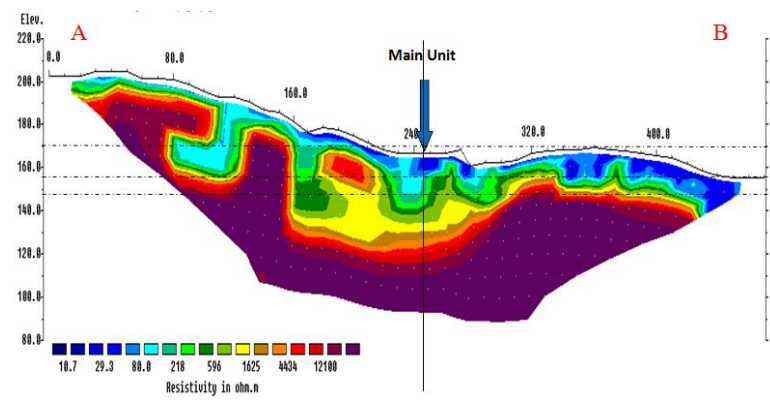

Gambar 3. Tampang lintang resistivitas bawah permukaan lintasan 2

Kesimpulan

Teridentifikasi akuifer air tanah dengan resistivitas $\leq 57,5 \Omega \mathrm{m}$. Terdapat 2 jenis akuifer air tanah yaitu air tanah permukaan yeng tersebar pada lintasan 1 dan 2 dengan keadalaman $\leq 20 \mathrm{~m}$, dan akuifer air tanah dalam dengan kedalaman $>20 \mathrm{~m}$. Akuifer air tanah dalam potensial di lintasan 1 pada meter ke 225 sampai 270 dengan kedalaman mencapai $60 \mathrm{~m}$.

\section{Daftar Pustaka}

As'ari dan Tongkukut, S. H., 2017. Identifikasi Potensi Cekungan Air Tanah Di Universitas Sam Ratulangi Menggunakan Eksplorasi Geolistrik Tahanan Jenis. Jurnal MIPA UNSRAT Online. Vol. 6 (2) 29--31

Hewaidy, A.G., El-Motaal, E.A., Sultan, S.A., Ramdan, T.M., El Khafif, A.A., Soliman, S.A. 2015. Groundwater exploration using resistivity and magnetic data at the northwestern part of the Gulf of Suez, Egypt. Egyptian Journal of Petroleum. Vol. 24(3), 255 - 263.

Koyong, M., Tamuntuan, G., Ferdy. 2017. Pemanfaatan Metode Geolistrik Konfigurasi Dipole-Dipole untuk Investigasi Sumber Air Panas di Kelurahan Paniki Bawah, Minahasa Utara. Jurnal MIPA UNSRAT online Vol. 6(2), 77 $-80$.

Sharifi, F., Arab-Amiri, A.R., Kamkar-Rouhani, A. 2014. Karstic Water Exploration Using The Schlumberger VES and Dipole-Dipole Resistivity Profiling Surveys in The Tepal Area, West of Shahrood, Iran. Journal of Mining and Environment Vol. 5(1), 1 - 12.

Sulu, S.S., As'ari, Tongkukut, S.H.J. 2015. Pemetaan Akuifer Air Tanah di Wilayah Kampus Unsrat Manado Dengan Menggunakan Metode Geolistrik Tahanan Jenis. Jurnal IImiah Sains Vol. 15(1), 20 - 26.
Suryo, D.K., Supriyanto, Djayus. 2016. Studi Sebaran Potensi Air di Kelurahan Tanah Merah Kecamatan Samarinda Utara Berdasarkan Resistivitas Batuan. Prosiding Seminar Sains dan Teknologi FMIPA Unmul, 434 - 439.

Telford, W.M., Geldart, L.P., Sheriff, R.E. 1990. Applied Geophysics $2^{\text {nd }}$ Edition. Cambridge University Press, USA.

Waluyo, dkk. 2005, Buku Panduan Workshop Geofisika. Laboratorium Geofisika Program Studi Geofisika UGM, Yogyakarta.

Wijaya, A.S. 2015. Aplikasi Metode Geolistrik Resistivitas Konfigurasi Wenner untuk Menentukan Struktur Tanah di Halaman Belakang SCC ITS Surabaya. Jurnal Fisika Indonesia Vol. 119 (5), 1 -5. 